\title{
7. ブニヤウイルスとその生態
}

\author{
吉 松 組 子, 有 川 二 郎
}

北海道大学大学院医学研究科微生物学講座病原微生物学分野

\begin{abstract}
ブニヤウイルスは，ブニヤウイルス科オルソブニヤウイルス属，ハンタウイルス属，ナイロウイル ス属，フレボウイルス属抢よびトスポウイルス属に分類されるウイルスの総称である，植物に病原性 を有するトスポウイルス属以外は，春椎動物に感染し，人や動物に重篤な疾患を引き起こす，いずれ も, 医学・獣医学・農学領域で重要な疾病であり, その多くが人獣共通感染症である（図 1). ハン タウイルス属以外は, 節足動物をべクターとするアルボウイルスであるが, 自然界における感染環に は属間で相違がある。近年，ハンタウイルスの自然宿主としてげっ歯目以外にトガリネズミ目の動物 が重要な役割を担っていることが明らかになった。また，フレボウイルス属のウイルスを原因とし， 血小板減少と発熱を特徵とする重篤な疾患が中国で新たに出現し ${ }^{1,2)}$, その後, 米国でも存在が確認 され新興感染症として注目されている。
\end{abstract}

\section{はじめに}

ブニヤウイルスは, 3 分節のマイナス鎖 RNA を保有し， 4 種の構造蛋白をもち, 細胞質内で増殖するという共通の 性質をもつ一群のウイルスの総称である。人や春椎動物を 宿主とする 4 属と植物を宿主とする 1 属の, 合わせて 5 属 よりなる．95種のウイルス種（virus species）と登録され ているウイルス株を会わせると 300 以上になる最大のウイ ルス科である ${ }^{3,4)}$. 表 1 に示すようなウイルス学的共通性 から，ブニヤウイルスは，共通の祖先ウイルスから分化し て来たと考えられるが，それぞれの属間ではウイルスの生 物学的性状，複製機構また自然界での生態には大きな相違 が涊められる。このため, これら近縁のウイルス間での性 状の相違をウイルス学的に比較・研究することは, ウイル スの進化と適応のメカニズムを解析する上で興味深い。し

連絡先

$\overline{\mathbf{T}} 060-8638$

北海道札幌市北区北 15 条西 7 丁目

北海道大学大学院医学研究科微生物学講座病原微生物学 分野

TEL: 011-706-6905

FAX: 011-706-6906

E-mail:j_arika@med.hokudai.ac.jp yosimatu@med.hokudai.ac.jp
かし、リバースジェネティクス法の開発は, オルソブニヤ ウイルス (orthobunyavirus) 属 ${ }^{5)}$ とフレボウイルス (phlebovirus) 属のウイルス ${ }^{6}$ ) でのみ報告があり, ウイル 又学的解析手法の現状はウイルス属によって大きく異なっ ている。, 一方, これまで, ハンタウイルスは, げっ歯類由 来のウイルスで, げっ歯類と共進化してきたと考えられて 来た ${ }^{7,8)}$. しかしながら近年になって, げっ歯目とは分類上, 目 (order) の段階で異なる,トガリネズミ目 (Soricomorpha, 元の食虫類）のトガリネズミ科やモグラ科に分類される多 くの動物に多種類のハンタウイルスが存在していることが明 らかになった。このため, ハンタウイルスはトガリネズミ目 由来である可能性も示され, ハンタウイルスの生態が大きく 見直されようとしている ${ }^{9)}$.また, 2010 年, 血小板減少と発 熱を特徵とする疾患 (severe fever with thrombocytopenia syndrome: SFTS）が中国で報告され，新種のフレボウイ ルス属に分類されるウイルスが分離された ${ }^{1,10)}$. 同様のウ イルスによる疾患が米国にも存在していたことが 2012 年 になって明らかにされ，新興感染症として注目されている11). 本稿では, ブニヤウイルスの各属の特徴について概説し たあと, 近年のトガリネズミ目由来ハンタウイルスの生態 学的な発見と, 新興感染症である SFTS とそのウイルス についての最近の知見をもとに，ブニヤウイルスの生態の 多様性について紹介したい.

\section{ブニヤウイルス科の分類}

ブニヤウイルス科のウイルスは, RNA 分節の大きさ， 


\section{表 1 ブニヤウイルス科に属するウイルスの共通性}

1. 球形 (直径 80- $120 \mathrm{~nm}$ )

2.エンベロープに糖タンパクのスパイク $(\mathrm{Gn}$ と $\mathrm{Gc})$ を保有

3.ビリオン内部には, ゲノム RNA, 核タンパク質（N）およびRNA ポリメラーゼ（Lタンパク質）を保有

4.ゲノムはマイナス一本鎖 RNA で三本の分節 S,M,L に分かれる

5. 各分節の両端の十数塩基が互いに相補的に結合し, パンハンドルと呼ばれる環状構造を形成

6. 複製は細胞室内で行われる

7. ビリオンはゴルジ体内に出芽して形成される

8. 近縁ウイルスが細胞に重感染すると遺伝子の再集合（リアソートメント）が起きる

表 2 人, 動物, 植物に疾患を引き起こすブニヤウイルス科のウイルス

\begin{tabular}{|c|c|c|c|c|c|}
\hline 属 (ウイルス種数) & 主なウイルス種 & ヒト疾患 & 自然宿主 & ベクター & 流行地域 \\
\hline \multirow{3}{*}{$\begin{array}{c}\text { オルソブニヤウイルス } \\
(48)\end{array}$} & ラクロスウイルス & 脳炎 & げっ歯類 & 力 (吸血) & 北米 \\
\hline & ブニヤムウェラウイルス & 熱性疾患 & げっ歯類 & 力 (吸血) & アフリカ•北·南米 \\
\hline & アカバネウイルス & ウシ・ヒツジ胎児の奇形 & 反赐獣 & 力 (吸血) & $\begin{array}{l}\text { 東アジア, 中近東, } \\
\text { アフリカ, 南米 }\end{array}$ \\
\hline \multirow{4}{*}{$\begin{array}{c}\text { ハンタウイルス } \\
(23)\end{array}$} & ハンターンウイルス & \multirow{2}{*}{ 腎症候性出血熱 } & \multirow{4}{*}{ げっ歯類 } & \multirow{4}{*}{ なし } & \multirow{2}{*}{ ユーラシア大陸全域 } \\
\hline & プーマラウイルス & & & & \\
\hline & シンノンブレウイルス & \multirow{2}{*}{ ハンタウイルス肺症候群 } & & & 北米 \\
\hline & アンデスウイルス & & & & 南米 \\
\hline $\begin{array}{c}\text { ナイロウイルス } \\
\text { (7) }\end{array}$ & $\begin{array}{l}\text { クリミア・コンゴ出血熱 } \\
\text { ウイルス }\end{array}$ & 出血熱 & ウシ·草食動物, 鳥 & マダニ (吸血) & アフリカ•中央アジア \\
\hline \multirow{2}{*}{$\begin{array}{c}\text { フレボウイルス } \\
\text { (9) }\end{array}$} & $\begin{array}{l}\text { リフトバレー熱ウイル } \\
\text { ス }\end{array}$ & 出血熱·脳炎 & 家畜・げっ歯類 & 力 (吸血) & \multirow{2}{*}{$\begin{array}{l}\text { 東·南·中央アフリカ, } \\
\text { 地中海地域·中央アジ } \\
\text { ア, インド, 中南米 }\end{array}$} \\
\hline & $\begin{array}{l}\text { サンドフライフィーバー } \\
\text { ウイルス }\end{array}$ & 熱性疾患 & 不明 & スナバエ (吸血) & \\
\hline $\begin{array}{c}\text { トスポウイルス } \\
\text { (8) }\end{array}$ & $\begin{array}{l}\text { トマト黄化萎縮ウイル } \\
\text { ス }\end{array}$ & 感染性なし & 植物·農作物 & アザミウマ & 全世界 \\
\hline
\end{tabular}

構造蛋白の大きさ，およびウイルス RNA の 3’と 5’末端の 8 から 11 塩基の相同性をもとに, オルソブニヤウイルス属, ハンタウイルス属, ナイロウイルス属, フレボウイルス属 拉よびトスポウイルス属の 5 属に分類される。 さらに，そ れぞれの属に分類されるウイルスは，抗原性，遺伝子の相 同性，生態学的相違などによってウイルス種（virus species）に分類されている (http://www.ictvonline.org/ virusTaxonomy.asp） ${ }^{12)}$ ，各属には，表 2 に示す様に多数 のウイルス種が登録されている。しかし，十分な解析がさ れないまま，経過的に分類されているものもある。一方， 歴史的に，抗原性をもとにする分類も行われている。オル ソブニヤウイルス属では補体結合試験 $(\mathrm{CF})$, 中和試験 (NT), 赤血球凝集阻止試験（HI）の成績をもとに 18 の 血清型（serogroup）が構成され，各血清型のウイルスは さらに, "viruses”, "types", "subtypes”, “varieties”と分 類されてきた。また，フレボウイルス属では“antigenic complex”という分類も用いられている。このため, 各属 に分類されるウイルスを“species”ではなく, "group” という用語で分類する方式もある ${ }^{4)}$ 。このような分類の複
雑性は，多数の多様なウイルスが野生動物を中心に世界的 に分布し，長年にわたり血清学的に分類されて来たという 本科のウイルスの特徵を反映していると思われる，今後， 遺伝的解析成績の蓄積と共に，分類が整理されていくと思 われる。

\section{ブニヤウイルスによって引き起こされる疾患}

表 2 に人，動物，植物に疾患を引き起こすブニヤウイル ス科のウイルスをまとめて示した。前述したように，トス ポウイルス属が植物に病原性を示すがその他は全て人，野 生動物または家畜に感染し，重篤な疾患を引き起こす場合 がある。また，ハンタウイルス属以外は，いずれも節足動 物をべクターとするアルボウイルスである。 ウイルス種毎 に，媒介節足動物の種類が異なる。しかし，オルソブニヤ ウイルス属のラクロスウイルス ${ }^{13)}$ ，フレボウイルス属の フレボウイルス拉よびリフトバレー熱ウイルス ${ }^{14)}$ ，ナイ ロウイルス属のクリミア・コンゴ出血熱ウイルス ${ }^{15)}$ では, それぞれ，蚊やダニがベクターとなり，さらに経卵巣感染 （transovarial transmission）が成立することが報告されて 


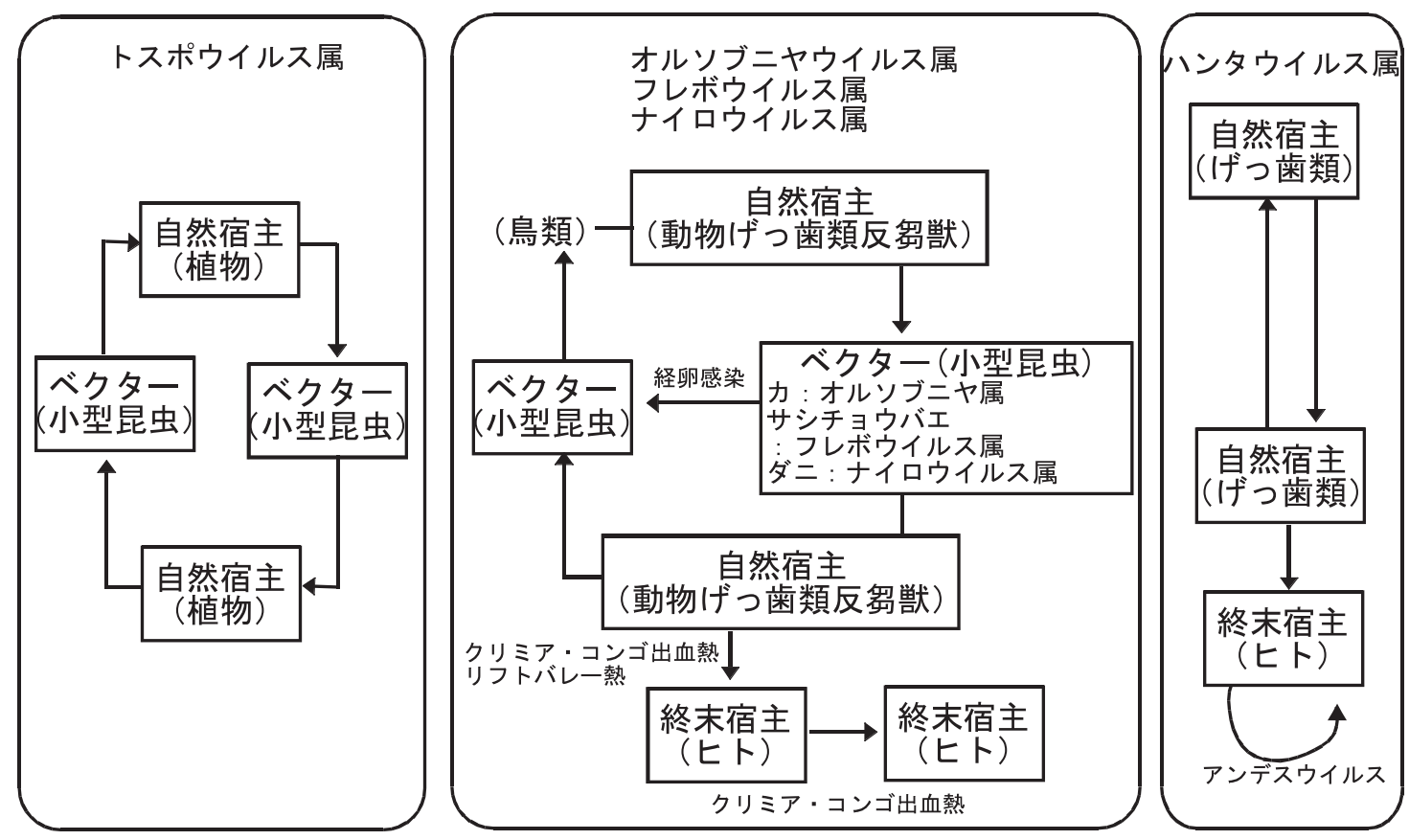

図 1 ブニヤウイルスの感染環

いる（図 1). すなわち, ブニヤウイルスは, 持続感染し ている春椎動物等の自然宿主を必ずしも必要とせずに, ベ クター自身を宿主として自然界で存続することができるこ とになる。しかし，ウイルスの存続における春椎動物自然 宿主の役割については不明な点が多く残されている.一方, ハンタウイルスでは，これまで，節足動物をべクターとす る報告はなく，持続感染しているげっ歯類等から排泄され る糞尿や唾液を介した飛沫感染によって感染が伝播し, 自 然宿主動物集団でウイルスが維持されていると考えられて いる16,17). しかし, 流行地で得られた tickや miteがヒト への感染性を有する成績や ${ }^{18)}$, それらからハンタウイル

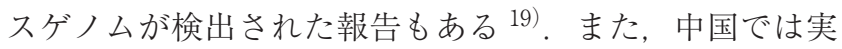
験感染マウスを吸血させた mite においてウイルスの増殖 や経卵巣感染が成立したとの報告がある 20,21$)$ 。今後さら なる確認が必要である。

\section{ブニヤウイルスの基本構造}

ブニヤウイルスのゲノムは，マイナス鎖 RNA で，長さ の異なる 3 分節に分かれている（図 2). 大きさにより L (large) 分節 $(6.4 \sim 12.2 \mathrm{~kb}), \mathrm{M}$ (medium) 分節 (3.5 4.9 $\mathrm{kb}), \mathrm{S}$ (small) 分節 $(1.0 \sim 2.9 \mathrm{~kb})$ と称される. L 分節は L タンパク（RNA 依存性 RNA ポリメラーゼ, 250 450 $\mathrm{kDa}), \mathrm{M}$ 分節はエンベロープ糖タンパクである $\mathrm{Gn}$ と $\mathrm{Gc}$ (35〜70 kDa), S 分節は核タンパク $\mathrm{N}(25 \sim 50 \mathrm{kDa})$ をコー ドする. 以前, エンベロープ糖タンパクは, 分子量の大き いものを G1 小さい方を G2 と呼んでいたが, 現在は, 翻 訳されるときに $\mathrm{N}$ 末端側にコードされているものを $\mathrm{Gn}$, $\mathrm{C}$ 末端側にコードされているものを Gc と呼ぶようになっ
ている，構造蛋白の大きさは，属によって異なるが, 基本 的な構造や機能は同一である。また, オルソブニヤウイル ス属, フレボウイルス属およびトスポウイルス属のウイル スが非構造蛋白（NS）をもつが, 属によってコード様式 が異なる，オルソブニヤウイルスでは， M 分節の Gn と Gc のコード領域の間に位置し，NSm と呼ばれる。また， $\mathrm{S}$ 分節では $\mathrm{N}$ タンパクのコード領域中にオーバーラップ フレームとして存在し, NSs と呼ばれる。また, フレボ ウイルスでは NSs がアンビセンス（ウイルス RNAの3' 側からの約半分がマイナス鎖, 後半がプラス鎖となってい る構造（アンビ (ambi-) とは両側という意味で, プラス とマイナスの両方のセンスであることによる）として S 分節の5側にコードされている。トスポウイルスでは $\mathrm{NSm}$ と NSs がそれぞれ M 分節と S 分節にアンビセンス として 5 側にコードされている。ブニヤウイルスのゲノ ム構造と翻訳の方向を図 2 にまとめた。

\section{ブニヤウイルスの複製}

ブニヤウイルスの細胞に吸着以後の複製の様式につい て，図 3 に概要を示した。以下，それぞれのステップでの ブニヤウイルスの特徵を記載する。吸着, 侵入後の脱殼 (uncoating) は，エンドゾーム膜とウイルスエンベロープ の低 $\mathrm{pH}$ 下での膜融合によって起こり, その後の転写, 翻 訳, 粒子形成またゲノムの複製は全て細胞質内で行われる. また, 転写は, L タンパクのエンドヌクレアーゼ活性によっ て, 宿主細胞の mRNA の 5 末 未端のキャップ構造を含む 10〜13 塩基を切り出し，それをプライマーとして利用す るキャップスナッチによって行われる ${ }^{22)}$. エンベロープ 


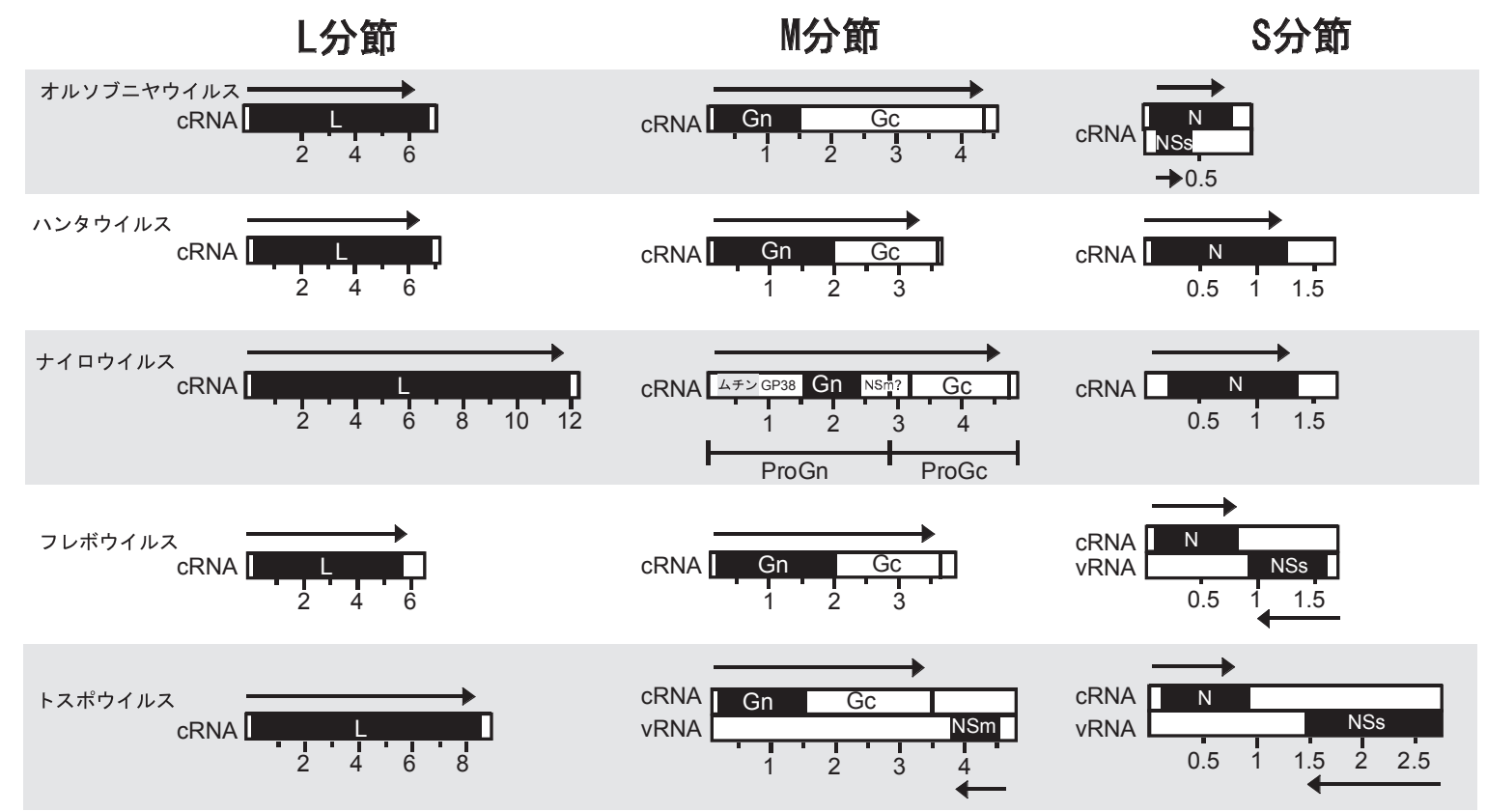

図 2 ブニヤウイルスのゲノム構造

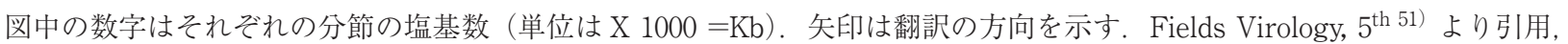
一部改変

糖タンパク $(\mathrm{Gn}$ と $\mathrm{Gc})$ は粗面小胞体上で翻訳・合成され, 糖鎖付加が行われて合成が完了した後, ゴルジ腔内に蓄積 する. 同時に, L タンパクと $\mathrm{N}$ タンパクの合成並びにウ イルスゲノムの複製が細胞質内で行われ，L， N タンパク およびウイルスゲノムによって構成されるリボヌクレオプ ロテインである, ヌクレオカプシドが形成される。形成さ れたヌクレオカプシドは，ゴルジ体膜上に蓄積されたエン ベロープ糖タンパクと細胞質側で会合する. その後, ゴルジ 体内側に出芽してビリオンとなり, 細胞外に放出される ${ }^{23)}$.

\section{トガリネズミ目由来ハンタウイルスの生態}

ハンタウイルスは腎症候性出血熱（hemorrhagic fever with renal syndrome: HFRS）とハンタウイルス肺症候群 (hantavirus pulmonary syndrome: HPS) の原因ウイルス である。これら疾患の原因となるハンタウイルスや病原性 が現在不明のハンタウイルスも含め, いずれも, 不顕性に 持続感染しているげっ歯類を自然宿主としていることが特 徵である。ささらに, 宿主げっ歯類のミトコンドリア DNA 塩基配列に基づく進化系統樹とウイルス RNA の塩基配列 にもとづく進化系統樹が良く一致することから，ハンタウ イルスはげっ歯類と共進化して来た可能性が示唆されてい る. 現在, 23 の virus species が ITCV 8thでは登録され ているが3), それらは, virus species 毎に特有の種のネズ ミを宿主としている。このため, HFRS と HPS の流行地 域は宿主げっ歯類の生息地域と一致し, HFRS はユーラシ ア大陸全域で, HPS は南北アメリカ大陸の諸国で発生が
みられる ${ }^{24)} .23$ の virus species 中, 唯一の例外が, イン ドで捕獲されたジャコウネズミ（ネズミというが，分類上 は，もとの食虫類であるトガリネズミ目 Suncus murinus) から分離された Thottaparalam virus（トッタパラヤンウ イルス，TPMV）である ${ }^{25)}$ 。これまでも，トガリネズミ 目に分類される小型ほ乳類にハンタウイルス抗体や抗原が 検出され, 感染が疑われて来た ${ }^{26)}$ 。 しかし, ウイルス分 離がなされなかったことから感染を確定することが出来 ず，TPMVが例外と考えられて来た，しかし，Yanagihara らは，丹念にPCR 法開発を行い，トガリネズミ目トガリ ネズミ科抢よびモグラ科に分類され世界各地に生息する多 種類のほ乳類からハンタウイルスゲノムを検出することに 成功した，表 3 に，これまでに報告されているトガリネズ ミ目由来ハンタウイルスを示した。ゲノムのみ検出されて いるものに加え, Imjin virus (MJNV) やCao Bang virus (CBNV) ではウイルス分離にも成功し，トガリネズミ目 の動物の間に多くのハンタウイルスが存在していることが 初めて明らかになった。

図 4 に, げっ歯目とトガリネズミ目由来ハンタウイルス $\mathrm{S}$ 分節の塩基配列に基づく系統樹を示した。それぞれ virus speciesの略語を太字で, tentative virus species の

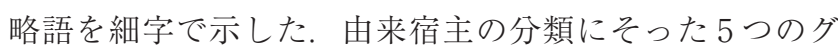
ループに分かれる。すなわち，げっ歯目としては，ネズミ 科ネズミ亜科（マウスやラット）由来 (Group I), キヌゲ ネズミ科ハタネズミ亜科（ハタネズミやレミング）由来 (Group II), キヌゲネズミ科アメリカネズミ亜科とウッド 


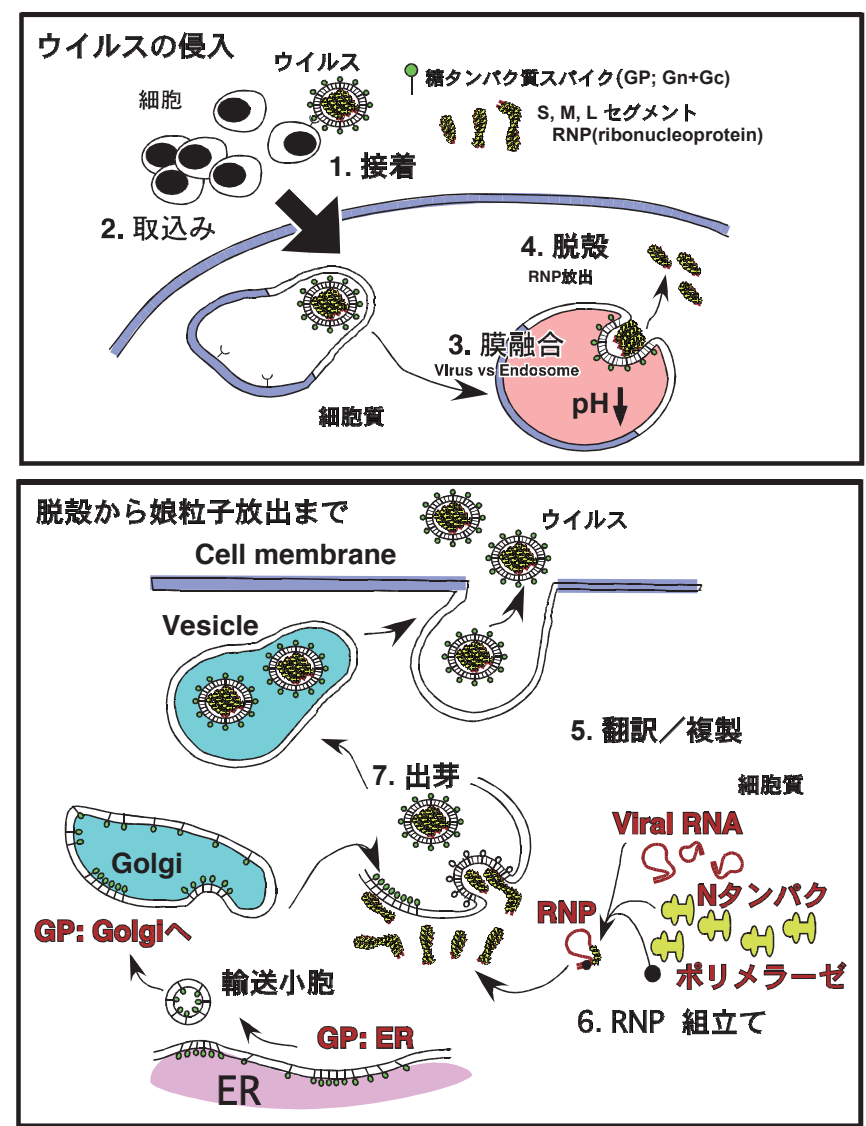

図 3 ブニヤウイルスの複製

上段にウイルスの侵入過程，細胞接着から脱殼までを示した。下段に脱殼から娘粒子放出までを示した．Fields Virology，5 $\left.5^{\text {th }} 51\right)$ より引用, 一部改変

表 3 トガリネズミ目動物由来ハンタウイルス

\begin{tabular}{|c|c|c|c|c|c|}
\hline ウイルス種 & 略号 & 起源 & 宿主 & 引用文献 & ウイルス分離 \\
\hline Thottapalayam & TPMV & India & Suncus murinus, Asian house shrew & Carey et al (2007) ${ }^{25)}$ & $\bigcirc$ \\
\hline Imjin & MUNV & Korea & Crocidura lasiura, Ussuri white-toothed shrew & Song et al (2009) ${ }^{41)}$ & $\bigcirc$ \\
\hline Tanganya & TGNV & Guinea & Crosidura theresae, Therese shrew & Klempa et al (2007) ${ }^{42)}$ & - \\
\hline Nova & NVAV & Hungary & Talpa europaea, European common mole & Kang et al (2009) ${ }^{43)}$ & - \\
\hline Asama & ASAV & Japan & Urotrichus talpoides, Japanese shrew mole & Arai et al $(2008)^{44)}$ & - \\
\hline Oxbow & OXBV & USA & Neurotrichus gibbsii, American shrew mole & Kang et al (2009) ${ }^{45)}$ & - \\
\hline Camp Ripley & RPLV & USA & Blarina brevicauda, northern short-tailed shrew & Arai et al $(2007)^{46)}$ & - \\
\hline Cao Bang & CBNV & Vietnam & Anourosorex squamipes, Chinese mole shrew & Song et al $(2007)^{47)}$ & $\bigcirc$ \\
\hline Seewis & SWSV & Switzerland & Sorex araneus, Eurasian common shrew & Song et al (2007) ${ }^{48)}$ & - \\
\hline Ash river & ARRV & USA & Sorex cinereus, masked shrew & Arai et al (2008) ${ }^{49)}$ & - \\
\hline Jemez Spring & JMSV & USA & Sorex monticolus, dusky shrew & Arai et al (2008) ${ }^{49)}$ & - \\
\hline Kenkeme & - & Siberia & Sorex roboratus, Flat-Skulled Shrew & Kang et al (2010) ${ }^{50)}$ & - \\
\hline
\end{tabular}




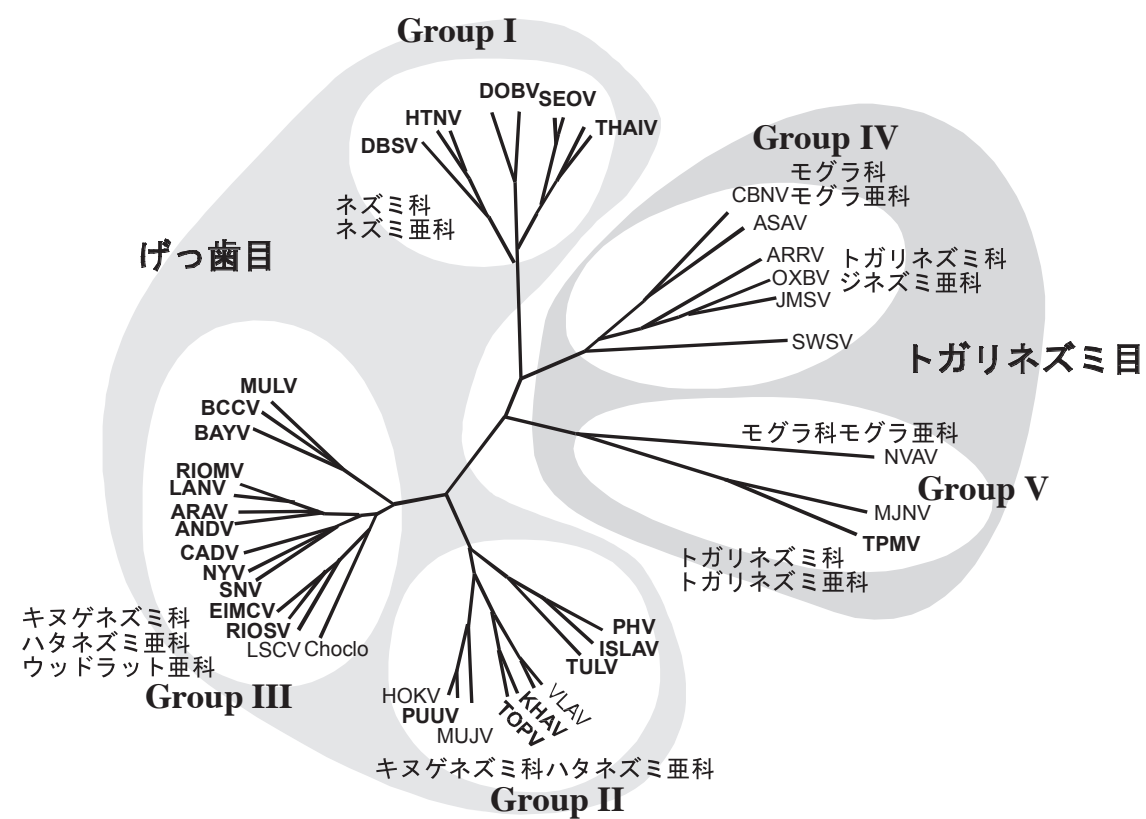

図4ハンタウイルス属に属するウイルスの系統樹

げっ歯目とトガリネズミ目由来ハンタウイルス S 分節の塩基配列に基づく系統樹を示す. Bunyaviridae, Molecular and Celluar Biology ${ }^{52)}$ より引用，一部改変.

ラット亜科 (北·南アメリカのマウスとラット)由来 (Group III), トガリネズミ目として, トガリネズミ科ジネズミ亜 科とモグラ科モグラ亜科由来 (GroupIV) と, 同じくトガ リネズミ科トガリネズミ亜科とモグラ科モグラ亜科由来 (GroupV) である。このように, 由来宿主の分類に一致し たウイルスの系統樹が描かれることから, ハンタウイルス はげっ歯目のみならず，トガリネズミ目に分類される宿主 とも共進化してきたと考えられる。

この図は同時に，トガリネズミ目の祖先がハンタウイル スを保有し，共進化を遂げながら，トガリネズミ科や一部 のげっ歯目にウイルスの感染が拡大して宿主を変えながら 適応して来た可能性を示唆する。げっ歯類由来ハンタウイ

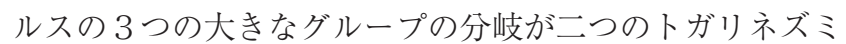
目由来ハンタウイルスを挟んだ形でみつかることから, げっ歯類へのハンタウイルスの感染が，トガリネズミ目の ウイルスからのホストスイッチであったと考えられる。こ の仮説では, 膨大なげっ歯目の中で 3 亜科に属する動物の みからハンタウイルスが検出されていることも説明でき る. また, ハンタウイルス属以外の全てのブニヤウイルス が，アルボウイルスである事を考えると，ハンタウイルス の祖先は, 昆虫類のウイルスであり, それが, げっ歯目の 祖先に host switching したのかもしれない.トガリネズミ 目は, 以前は食虫類と呼ばれていたように, 昆虫類を食餌 とすることから, 昆虫ウイルスが感染する機会もあると考 えられる, ウイルスと宿主の適応の結果, 昆虫ベクターを 必要としない感染環を確立したのかもしれない.
中国 ${ }^{27)}$ ，タイ ${ }^{28) ， イ ン ト ゙ ネ シ ア ~}{ }^{29)}$ 抢よびベトナム ${ }^{30,31,32)}$ で行われた調查では TPMVに対する抗体陽性あるいはゲ ノム陽性トガリネズミが報告され，東アジアを中心に広く TPMV が分布していると思われる。しかし，ヒトの感染 例の報告は，ラオスの熱性疾患例， 1 例で TPMV に対す る抗体陽性例が報告されているのみである ${ }^{29)}$. しかし， この症例も IgM 抗体は陰性であり疾患との関連は不明で ある. TPMV と他の HFRS 原因ハンタウイルスとは抗原 的に大きく隔たっているため, これまでの不明熱患者を対 象としたハンタウイルス血清疫学的調査では, TPMV 抗 体陽性例を発見出来ない可能性がある。 今後, TPMVや トガリネズミ目由来ハンタウイルスを抗原とした調查が, この新たに発見されたハンタウイルスの人への病原性を明 らかにするためには必要である.

\section{血小板減少症を伴う重症熱性症候群}

\section{(severe fever with thrombocytopenia syndrome: SFTSV)}

2007 年 5 月以降，中国河南省に扔いて，発熱，血小板 減少, 胃腸症状, 白血球減少を特徵とする疾患が多数発生 し， 2007 年中に合計 79 例が報告され，内，10 例が死亡し た ${ }^{33)}$ 。その後も発生は続き, 2009 年 3 月末から 7 月半ば にかけて, 湖北省中心部と河南省の農村部でも同様の疾患 が多数発生し, 当初の死亡率は 30\%に達した ${ }^{1)}$ 。2 009 年 6 月の時点では, 症状の類似性からアナプラズマ症（別名, ヒ下 顆粒球アナプラズマ症, Human granulocytic anaplasmosis, グラム陰性桿菌であるAnaplasma phagocytophilum を原因 


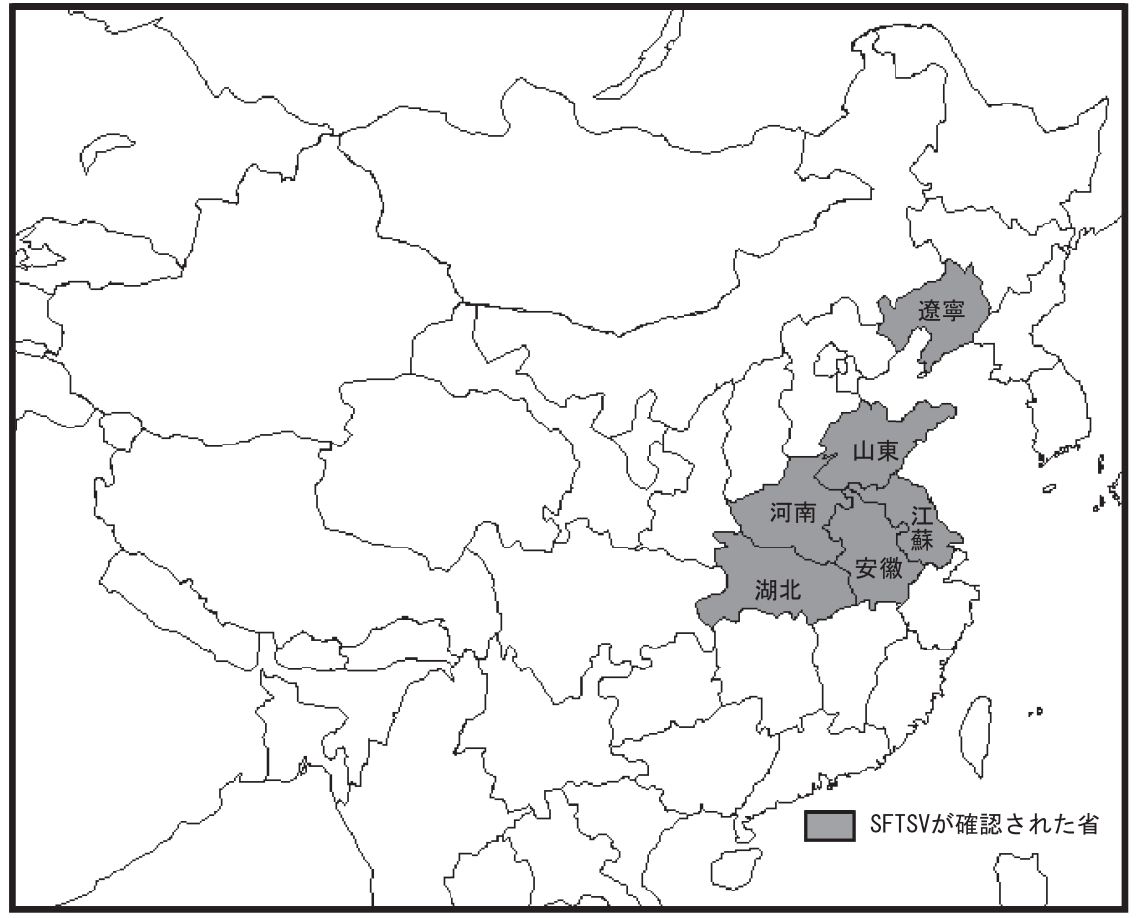

図 5 中国でSFTSV 感染が確認された省

とする）が疑われたが，抗体検查や PCR 診断の結果から 否定され，原因の特定に至らなかった，その後，2010 年 3 月までに, 中国中央部から東北部にかけての 6 省（遼寧, 湖北, 山東，江蘇，河南，安徽省）（図 5）で同様の疾患 の発生が確認された。このため, 中国疾病予防対策センター (Chinese CDC) はこの疾患を血小板減少症を伴う重症熱 性症候群 (severe fever with thrombocytopenia syndrome: SFTS）と命名し，上記のそれぞれの省の疾病予防対策セ ンター (Province CDC) と共同で原因病原体の解明にあ たった。最終的に，ブニヤウイルス科フレボウイルス属 に分類される新たなウイルス (SFTSV) が分離された ${ }^{1)}$. 最初のウイルス分離は, 河南省の 42 歳の男性から得られ た, 発症 7 日後の白血球をヒト由来 HL60 細胞, 動物由来, DH82, L929, Vero, Veo E6 お」よびダニ由来細胞 ISE6 細胞 と共培養することで行われた。 その結果, イヌ由来単球細 胞 DH82 細胞で細胞の円形化を示す CPE が出現し, 細胞 質内に顆粒状のものが認められた。また，患者血清を用い た IFA 法で細胞質中にSFTSV 抗原の存在が確認された。 SFTSV はその他の細胞にも感染したが，CPEを起こすの は，DH82 細胞のみであった，その後，近隣の省の患者よ り得られた急性期血清より，Vero 細胞を用いて 11 株の分 離に成功した。感染細胞の透過型電子顕微鏡による観察か ら, ブニヤウイルスの形態学的特徵を示す, 直径 80〜100 $\mathrm{nm}$ の球形のウイルス粒子がゴルジ体と思われ器官内の小 胞中に認められた。

それら 12 株の感染細胞上清から VIDISCA 法 ${ }^{34)}$ と
SISPA 法 ${ }^{35)}$ によって, RNA の塩基配列が決定され，ブ ニヤウイルス科フレボウイルス属の $\mathrm{L}, \mathrm{M}$, 抒よび $\mathrm{S}$ 分節 RNA と最も相同性高い（96\%）配列であることが明らか になった。 さらに, S 分節ではフレボウイルスで認められ るような, $\mathrm{N}$ とSs に相当する 2 種の蛋白がアンビセン スとしてコードされていた。 また，ウイルスゲノムの末端 配列はフレボウイルス属のものと一致していた。塩基配列 とアミノ酸配列に基づく系統樹解析でも既存のフレボウイ ルス属のウイルスと最も近縁であることが確認された（図 6).しかし, SFTSV はフレボウイルス属中の既存の 2 つの ウイルスグループ(サンドフライフィーバーウイルス (Sandfly fever virus）㧍よびウークニエミウイルス（Uukuniemi virus））のいずれとも同程度に隔たっており，また，フレ ボウイルスの中で唯一ダニをべクターとするなどの相違か らも,第3のウイルスグループとなることが示されている. 急性期と回復期血清が得られた症例のうち, RT-PCR 法 でウイルスゲノムが検出された 35 例は, IFA， ELISA お よび中和試験で全例が抗体陽性であった，特に，高い中和 抗体価が回復期血清には認められ, さらに 1 年間以上持続 する事も明らかになった。

SFTSV 感染が確認された 81 例についての臨床症状は, 発熱, 胃腸症状, リンパ節腫脹等の一般的症状が中心であっ たが. 臨床検査では，95\%に血小板減少，86\%に白血球 減少が認められた。多藏器不全が多くの例で認められ, 84\%に蛋白尿が，59\%に血尿が認められた。また，2009 年 6 月から 2010 年 9 月までに入院した患者のうち, 中国 


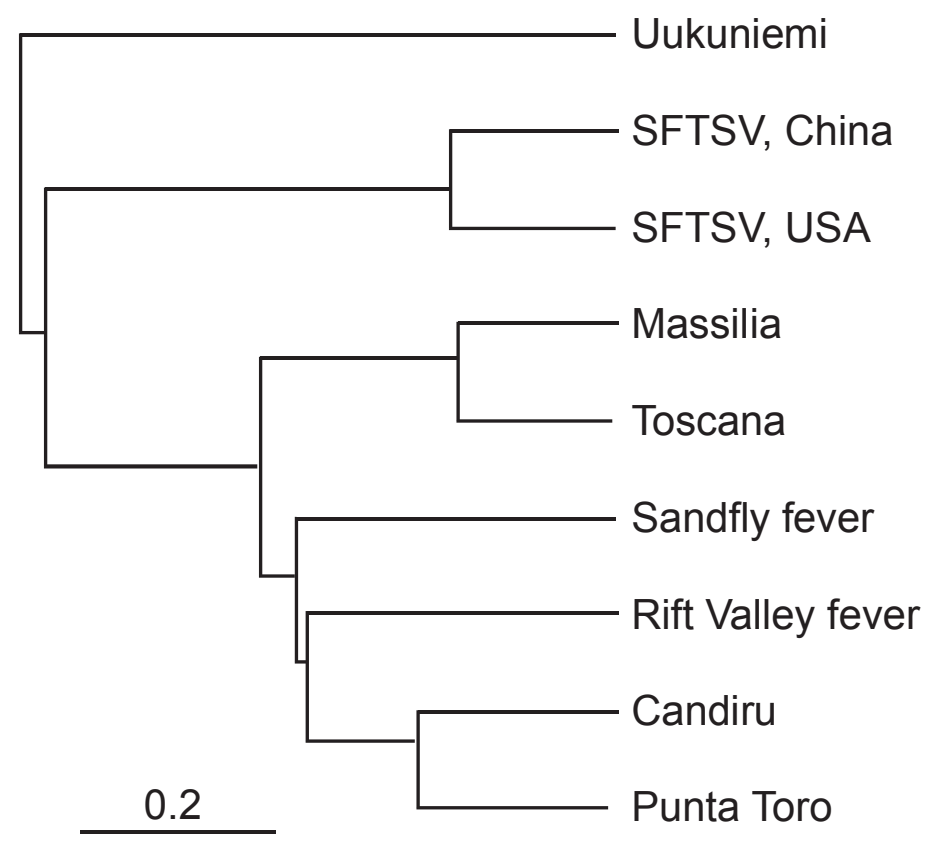

図 6 フレボウイルス属に属するウイルスの系統樹

フレボウイルス M 分節の塩基配列に基づく系統樹を示す. MacMullan (2012) ${ }^{11)}$ より引用，一部改変.

が 2010 年に定めた本疾患診断のガイドラインによって SFTSV 感染が疑われた 241 例について再検査すると, 171 例がウイルス RNA もしくは抗体の検出によって SFTSV 感染が確認され，うち，21 例 (12\%) が死亡した。これ ら 171 例中， 2010 年に感染した 154 例では，それらの 148 例 (96\%) が 5 月から 7 月に報告され, 年齢は 39 から 83 歳, 115 人 $(75 \%)$ が 50 歳以上， $56 \%$ が女性で，患者の $97 \%$ が農民であった．患者の住居近辺で 5,900 匹の蚊を採取し て解析したがウイルス RNA は検出されなかった．しかし， 家畜から得られたダニ（フタトゲチマダニ, Haemaphysalis longicornis) 186 匹中 10 匹から SFTSVの RNA が検出され， Vero 細胞を用いてウイルスの分離も成功した。分離ウイ ルス塩基配列は SFTS 患者由来株と高い相同性を示した が，わずかな相違も認められた，Zhang らの報告でも流行 地由来のフタトゲチマダニのプールから 18 の陽性が検出 されており，陽性率は $4.9 \%$ であった。すなわち，ダニが ベクターと考えられ，その繁殖期に一致して 5 月から 7 月 にかけて流行が拡大したものと考えられる ${ }^{36)}$.

中国 CDC によるこの発表に前後して, 河南省の感染症 予防研究所でも, 中国 CDC との共同研究として, 河南省 准陽山（ファイヤンシャン, Huaiyangshan）近郊や湖北 省の流行地のウシ，ヤギ，イヌおよび茶畑で採取されたダ ニ(フタトゲチマダニ (Haemaphysalis longicorni とオウ シマダニ, (Rhipicephalus microplus)) のプール（各20匹) の約 1\%からウイルスRNA を検出し, ウイルス分離にも 成功した。分離場所の地名にならって疾患名を
Huaiyangshan hemorrhagic fever (HYSHF), ウイルスには, Huaiyangshan virus (HYSV) という名称を提唱した ${ }^{10)}$. 分離 ウイルスは先の SFTSV とも $96 \%$ 以上の相同性を示した。 江蘇省では，ヤギ (57\%), ウシ (32\%)，イヌ（5\%）また ニワトリ（1\%）にSFTSV 抗体陽性，山東省では, 2011 年 8 月に 134 匹のヤギの抗体測定を行い，111 例（83\%） が抗体陽性であった ${ }^{37)}$ 。それら抗体陽性のヤギを飼育し ている村に生活する人々 237 例の抗体検查では, 2 例に抗 体陽性例を認めた。いずれも，SFTS 発症の記録はなく不 顕性感染したものと考えられている。このように, SFTSV はヤギ等の家畜を宿主として, ダニによって感染 が伝播すると考えられている。一方，患者血液との接触が 原因によるヒトからヒトへの直接伝播を示唆する報告があ る ${ }^{38,39)}$. 伝播ルートには不明な点も残されている.

また，最近になって，SFTSVを実験感染させたC57/ BL6 マウスに扔いても，血小板が減少することが報告さ れた ${ }^{40)}$. SFTSVが吸着した血小板がマクロファージ中に 多数観察され，ウイルス吸着血小板がマクロファージに よって取り込まれるためとする血小板減少のメカニズムが 提唱された。このように，コッホの 4 原則にほぼ則る形で 原因ウイルスが特定された。

このSFTSVの発見を契機として，同一ウイルスによる 感染例が米国ミズーリ州で発見された ${ }^{11)}$. 2009 年 6 月, ダニに吸血された 5 から 7 日後に発熱, 倦意, 下㾥, 血小 板減少および白血球減少を示した 2 例で，いずれもダニ媒 介性の細菌性疾患，エーリキア症（Ehrlichia chaffeensis） 
が疑われながら抗体検査, PCR 検査のいずれでも否定さ れた症例である。保存されていた，急性期の好中球を，中 国での報告で用いられたと同じ，イヌ由来 DH82 細胞に接 種し, ウイルス分離に成功した。電子顕微鏡像でも SFTSV と類似の分布と粒子形状を示し，さらに遺伝子系 統樹解析でも SFTSV とのみ同一のクラスターを形成した ことから, SFTSV 感染によるものであることが示された. さらに，発症後， 2 年を経過した 2011 年 10 月に，抗体価 を測定したところ，2 例いずれも 6,400 倍の高いELISA 抗 体価を維持し, 感染が持続する可能性も示唆されている. 症状もSFTS と類似していることから，米国での症例も SFTS と考えている。患者の生活圈で採取されたダニから はウイルスは検出されていないが，ダニがベクターとして 推察され，特に，主要な生息種であるキララマダニ属の一 種 (Amblyomma americanum) が, ベクターと推察され ている。このダニは米国の南部中央から東部にかけて広く 分布していることから未診断の本症が存在する可能性があ り,さらなる疫学的調查が必要であるとしている。

\section{終わりに}

ブニヤウイルス科ウイルスの概要と，近年明らかになっ た新たなブニヤウイルスについて紹介した，ブニヤウイル 久科は，様々な種の動物を自然宿主とし，多数のウイルス 種を保有する RNA ウイルス中最大の科である，今回，新 たなブニヤウイルスとして，トガリネズミ目由来ハンタウ イルス拉よびダニをべクターとする初めてのフレボウイル スとして SFTSVが発見された。この事実は，未知のウイ ルスが，現在もなお野生動物の間に存在していることを改 めて認識させるものである。野生動物由来の病原体による 新興感染症としての人獣共通感染症の重要性が指摘されて 久しい。これからも,サーベイランスの実施と迅速な解析・ 情報共有による病原体の封じ込めが重要である.

\section{引用文献}

1) Yu XJ, Liang MF, Zhang SY, Liu Y, Li JD, Sun YL, Zhang L, Zhang QF, Popov VL, Li C, Qu J, Li Q, Zhang YP, Hai R, Wu W, Wang Q, Zhan FX, Wang XJ, Kan B, Wang SW, Wan KL, Jing HQ, Lu JX, Yin WW, Zhou H, Guan XH, Liu JF, Bi ZQ, Liu GH, Ren J, Wang H, Zhao Z, Song JD, He JR, Wan T, Zhang JS, Fu XP, Sun LN, Dong XP, Feng ZJ, Yang WZ, Hong T, Zhang Y, Walker DH, Wang Y, Li DX, 2011. Fever with thrombocytopenia associated with a novel bunyavirus in China. N Engl J Med 364: 1523-32.

2 ) Zhang YZ, He YW, Dai YA, Xiong Y, Zheng H, Zhou DJ, Li J, Sun Q, Luo XL, Cheng YL, Qin XC, Tian JH, Chen XP, Yu B, Jin D, Guo WP, Li W, Wang W, Peng JS, Zhang GB, Zhang S, Chen XM, Wang Y, Li MH, Li Z, Lu S, Ye C, de Jong MD, Xu J, 2011. Hemorrhagic fever caused by a novel Bunyavirus in China: pathogenesis and correlates of fatal outcome. Clin Infect Dis 54: 527-33.
3 ) Nichol ST, Beaty BJ, Elliott RM, Goldbach R, Plyusnin A, Schmaljohn CS, Tesh RB, 2005. Bunyaviridae. Fauquet CM, Mayo MA, Maniloff J, Desselberger U, Ball LA, eds. Virus Taxonomy: Classification and Nomenclature of Viruses: Eighth Report of the International Committee on the Taxonomy of Viruses. San Diego, London, Tokyo: Elsevier Academic Press., 695-716.

4 ) Schmaliohn CS, Nichol ST, 2007. Bunyaviridae. Knipe DM, Howley PM, Griffin DE, Lamb RA, Martin MA, Roizman B, Straus SE, eds. Fields Virology. Philadelphia: Lippincott Williams \& Wilkins, 1741-1789.

5 ) Lowen AC, Noonan C, McLees A, Elliott RM, 2004. Efficient bunyavirus rescue from cloned cDNA. Virology 330: $493-500$.

6 ) Bouloy M, Flick R, 2009. Reverse genetics technology for Rift Valley fever virus: current and future applications for the development of therapeutics and vaccines. Antiviral Res 84: 101-18.

7 ) Plyusnin A, Vapalahti O, Lundkvist A, 1996. Hantaviruses: genome structure, expression and evolution. J Gen Virol 77: 2677-2687.

8 ) Jackson AP, Charleston MA, 2004. A cophylogenetic perspective of RNA-virus evolution. Mol Biol Evol 21: 45-57.

9 ) Kang HJ, Bennett SN, Hope AG, Cook JA, Yanagihara $\mathrm{R}, 2011$. Shared ancestry between a newfound moleborne hantavirus and hantaviruses harbored by cricetid rodents. J Virol 85: 7496-503.

10) Zhang YZ, Zhou DJ, Xiong Y, Chen XP, He YW, Sun Q, Yu B, Li J, Dai YA, Tian JH, Qin XC, Jin D, Cui Z, Luo XL, Li W, Lu S, Wang W, Peng JS, Guo WP, Li MH, Li ZJ, Zhang S, Chen C, Wang Y, de Jong MD, Xu J, 2011. Hemorrhagic fever caused by a novel tick-borne Bunyavirus in Huaiyangshan, China. Zhonghua Liu Xing Bing Xue Za Zhi 32: 209-20.

11) McMullan LK, Folk SM, Kelly AJ, MacNeil A, Goldsmith CS, Metcalfe MG, Batten BC, Albarino CG, Zaki SR, Rollin PE, Nicholson WL, Nichol ST, 2012. A new phlebovirus associated with severe febrile illness in Missouri. N Engl J Med 367: 834-41.

12) 2008. International Committee on Taxonomy of Viruses. Virus Taxonomy List, http://www.ictvonline.org/ virusTaxonomy.asp

13) Tesh RB, Gubler DJ, 1975. Laboratory studies of transovarial transmission of La Crosse and other arboviruses by Aedes albopictus and Culex fatigans. Am J Trop Med Hyg 24: 876-80.

14) Linthicum KJ, Davies FG, Kairo A, Bailey CL, 1985. Rift Valley fever virus (family Bunyaviridae, genus Phlebovirus). Isolations from Diptera collected during an inter-epizootic period in Kenya. J Hyg (Lond) 95: 197-209.

15) Wilson ML, Gonzalez JP, Cornet JP, Camicas JL, 1991. Transmission of Crimean-Congo haemorrhagic fever virus from experimentally infected sheep to Hyalomma truncatum ticks. Res Virol 142: 395-404.

16) Kariwa H, Kamimura M, Arikawa J, Yoshimatsu K, Takashima I, Hashimoto N, 1995. Characterization of the mode of Hantaan virus infection in adult mice 
using a nested reverse transcriptase polymerase chain reaction: transient virus replication in adult mice. Microbiol Immunol 39: 35-41.

17) Arikawa J, Ito M, Yao JS, Kariwa H, Takashima I, Hashimoto N, 1994. Epizootiological studies of hantavirus infection among urban rats in Hokkaido, Japan: evidences for the persistent infection from the seroepizootiological surveys and antigenic characterizations of hantavirus isolates. J Vet Med Sci 56:27-32.

18）笠原四郎, 北野政次, 菊地斉, 作山元治, 金沢謙一, 根 津尚光, 吉村済夫, 工藤忠雄, 1944. 流行性出血熱の病 原体決定.日本病理学会誌 34: 3-5.

19) Houck MA, Qin H, Roberts HR, 2001. Hantavirus transmission: potential role of ectoparasites. Vector Borne Zoonotic Dis 1:75-9.

20) Song G, Hang CS, Qui XZ, Ni DS, Liao HX, Gao GZ, Du YL, Xu JK, Wu YS, Zhao JN, Kong BX, Wang ZS, Zhang ZQ, Shen HK, Zhou N, 1983. Etiologic studies of epidemic hemorrhagic fever (hemorrhagic fever with renal syndrome). J Infect Dis 147: 654-9.

21) Song G, 1999. Epidemiological progresses of hemorrhagic fever with renal syndrome in China. Chin Med J (Engl) 112: 472-7.

22) Garcin D, Lezzi M, Dobbs M, Elliott RM, Schmaljohn C, Kang CY, Kolakofsky D, 1995. The 5' ends of Hantaan virus (Bunyaviridae) RNAs suggest a prime-andrealign mechanism for the initiation of RNA synthesis. J Virol 69: 5754-62.

23) Jonsson CB, Figueiredo LT, Vapalahti O, 2010. A global perspective on hantavirus ecology, epidemiology, and disease. Clin Microbiol Rev 23: 412-41.

24) Young JC, Mills JN, Enria DA, Dolan NE, Khan AS, Ksiazek TG, 1998. New World hantaviruses. British Medical Bulletin 54: 659-673.

25) Carey DE, REuben R, Panicker KN, Shope RE, Myers RM, 1971. Thottapalayam virus:A presumptive arbovirus isolated from a shrew in India. Ind J Med Res 59: 1758-1760.

26）橋本信夫, 森田千春, 1985. 腎症候性出血熱 ソ連の野 生小動物の抗原保有.獣医学 1985:199-227.

27) Guo WP, Lin XD, Wang W, Zhang XH, Chen Y, Cao JH, Ni QX, Li WC, Li MH, Plyusnin A, Zhang YZ, 2011. A new subtype of Thottapalayam virus carried by the Asian house shrew (Suncus murinus) in China. Infect Genet Evol 11: 1862-7.

28) Pattamadilok S, Lee BH, Kumperasart S, Yoshimatsu K, Okumura M, Nakamura I, Araki K, Khoprasert Y, Dangsupa P, Panlar P, Jandrig B, Kruger DH, Klempa B, Jakel T, Schmidt J, Ulrich R, Kariwa H, Arikawa J, 2006. Geographical distribution of hantaviruses in Thailand and potential human health significance of Thailand virus. Am J Trop Med Hyg 75: 994-1002.

29) Okumura M, Yoshimatsu K, Kumperasart S, Nakamura I, Ogino M, Taruishi M, Sungdee A, Pattamadilok S, Ibrahim IN, Erlina S, Agui T, Yanagihara R, Arikawa J, 2007. Development of serological assays for Thottapalayam virus, an insectivore-borne Hantavirus. Clin Vaccine Immunol 14: 173-81.

30) Koma T, Yoshimatsu K, Yasuda PS, Li TC, Amada T,
Shimizu K, Isozumi R, Mai le TQ, Hoa NT, Nguen T, Yamashiro T, Hasebe F, Arikawa J, 2012. A survey of rodent-borne pathogens carried by wild Rattus spp. in Northern Vietnam. Epidemiol. Infect. in press.

31) Vu Dinh L, Yoshimatsu K, Endo R, Taruishi M, Vo Thi H, Dang Tuan D, Pham Cong TS, K., Koma T, Yasuda PS, NIhi L, Vu Thi Que H, Arikawa J, 2012. Studies on hantavirus infection in small mammals captured in Southern and Central Highland area of Vietnam. J Vet Med Sci 74: 1155-1162.

32) Truong T-T, Yoshimatsu K, Araki K, Lee B-H, Nakamura I, Endo R, Shimizu K, Yasuda PS, Koma T, Taruishi M, Okumura M, Truong U-N, Arikawa J, 2009. Molecular epidemiological and serological studies of hantavirus infection in Northern Vietnam. J Vet Med Sci 71: 1357-1363.

33) Xu B, Liu L, Huang X, Ma H, Zhang Y, Du Y, Wang P, Tang X, Wang H, Kang K, Zhang S, Zhao G, Wu W, Yang Y, Chen H, Mu F, Chen W, 2011. Metagenomic analysis of fever, thrombocytopenia and leukopenia syndrome (FTLS) in Henan Province, China: discovery of a new bunyavirus. PLoS Pathog 7: e1002369.

34) Pyrc K, Jebbink MF, Berkhout B, van der Hoek L, 2008. Detection of new viruses by VIDISCA. Virus discovery based on cDNA-amplified fragment length polymorphism. Methods Mol Biol. 454.

35) Victoria JG, Kapoor A, Dupuis K, Schnurr DP, Delwart EL, 2008. Rapid identification of known and new RNA viruses from animal tissues. PLoS Pathog 4: e1000163.

36) Zhang YZ, Zhou DJ, Qin XC, Tian JH, Xiong Y, Wang JB, Chen XP, Gao DY, He YW, Jin D, Sun Q, Guo WP, Wang W, Yu B, Li J, Dai YA, Li W, Peng JS, Zhang GB, Zhang S, Chen XM, Wang Y, Li MH, Lu X, Ye C, de Jong MD, Xu J, 2012. The ecology, genetic diversity, and phylogeny of Huaiyangshan virus in China. J Virol 86: $2864-8$

37) Zhao L, Zhai S, Wen H, Cui F, Chi Y, Wang L, Xue F, Wang Q, Wang Z, Zhang S, Song Y, Du J, Yu XJ, 2012. Severe fever with thrombocytopenia syndrome virus, Shandong Province, China. Emerg Infect Dis 18: 9635.

38) Gai ZT, Zhang Y, Liang MF, Jin C, Zhang S, Zhu CB, Li C, Li XY, Zhang QF, Bian PF, Zhang LH, Wang B, Zhou N, Liu JX, Song XG, Xu A, Bi ZQ, Chen SJ, Li DX, 2012. Clinical progress and risk factors for death in severe fever with thrombocytopenia syndrome patients. J Infect Dis 206: 1095-102.

39) Liu Y, Li Q, Hu W, Wu J, Wang Y, Mei L, Walker DH, Ren J, Yu XJ, 2012. Person-to-person transmission of severe fever with thrombocytopenia syndrome virus. Vector Borne Zoonotic Dis 12: 156-60.

40) Jin C, Liang M, Ning J, Gu W, Jiang H, Wu W, Zhang F, Li C, Zhang Q, Zhu H, Chen T, Han Y, Zhang W, Zhang S, Wang Q, Sun L, Liu Q, Li J, Wang T, Wei Q, Wang S, Deng Y, Qin C, Li D, 2012. Pathogenesis of emerging severe fever with thrombocytopenia syndrome virus in C57/BL6 mouse model. Proc Natl Acad Sci U S A 109: 10053-8.

41) Song JW, Kang HJ, Gu SH, Moon SS, Bennett SN, 
Song KJ, Baek LJ, Kim HC, O'Guinn ML, Chong ST, Klein TA, Yanagihara R, 2009. Characterization of Imjin virus, a newly isolated hantavirus from the Ussuri white-toothed shrew (Crocidura lasiura). J Virol 83: 6184-91.

42) Klempa B, Fichet-Calvet E, Lecompte E, Auste B, Aniskin V, Meisel H, Barriere P, Koivogui L, ter Meulen J, Kruger DH, 2007. Novel hantavirus sequences in Shrew, Guinea. Emerg Infect Dis 13: 520-2.

43) Kang HJ, Arai S, Hope AG, Song JW, Cook JA, Yanagihara R, 2009. Genetic diversity and phylogeography of Seewis virus in the Eurasian common shrew in Finland and Hungary. Virol J 6: 208.

44) Arai S, Ohdachi SD, Asakawa M, Kang HJ, Mocz G, Arikawa J, Okabe N, Yanagihara R, 2008. Molecular phylogeny of a newfound hantavirus in the Japanese shrew mole (Urotrichus talpoides). Proc Natl Acad Sci U S A 105: 16296-301.

45) Kang HJ, Bennett SN, Dizney L, Sumibcay L, Arai S, Ruedas LA, Song JW, Yanagihara R, 2009. Host switch during evolution of a genetically distinct hantavirus in the American shrew mole (Neurotrichus gibbsii). Virology 388: 8-14.

46) Arai S, Song JW, Sumibcay L, Bennett SN, Nerurkar VR, Parmenter C, Cook JA, Yates TL, Yanagihara R, 2007. Hantavirus in northern short-tailed shrew, United States. Emerg Infect Dis 13: 1420-3.
47) Song JW, Kang HJ, Song KJ, Truong TT, Bennett SN, Arai S, Truong NU, Yanagihara R, 2007. Newfound hantavirus in Chinese mole shrew, Vietnam. Emerg Infect Dis 13: 1784-7.

48) Song JW, Gu SH, Bennett SN, Arai S, Puorger M, Hilbe M, Yanagihara R, 2007. Seewis virus, a genetically distinct hantavirus in the Eurasian common shrew (Sorex araneus). Virol J 4: 114.

49) Arai S, Bennett SN, Sumibcay L, Cook JA, Song JW, Hope A, Parmenter C, Nerurkar VR, Yates TL, Yanagihara $\mathrm{R}, 2008$. Phylogenetically distinct hantaviruses in the masked shrew (Sorex cinereus) and dusky shrew (Sorex monticolus) in the United States. Am J Trop Med Hyg 78: 348-51.

50) Kang HJ, Arai S, Hope AG, Cook JA, Yanagihara R, 2010. Novel hantavirus in the flat-skulled shrew (Sorex roboratus). Vector Borne Zoonotic Dis 10: 5937.

51) caption F, 2007. Bunyaviridae. Knipe DM, Howley PM, Griffin DE, Lamb RA, Martin MA, Roizman B, Straus SE, eds. Fields Virology. Philadelphia: Lippincott Williams \& Wilkins.

52) Sironene T, Plyusnin A, 2011. Genetics and evolution of hantaviruses. Plyusnin A, Elliott RM, eds. Bunyaviridae, Molecular and celluar biology. Norfolk: Caister Academic Press, 61-94. 


\title{
Bunyavirus and its ecology
}

\section{Kumiko YOSHIMATSU, Jiro ARIKAWA}

\author{
Department of Microbiology and Infectious Diseases, \\ Graduate School of Medicine, Hokkaido University \\ Kita-15, Nishi-7, Kita-ku, Sapporo 060-8637, Japan \\ E-mail:j_arika@med.hokudai.ac.jp \\ yosimatu@med.hokudai.ac.jp
}

The family Bunyaviridae consists of over 300 virus species and strains that are divided into 5 genera: orthobunyavirus, hantavirus, nairovirus, phlebovirus, and tospovirus. All members of family Bunyaviridae possess a negative-sense, single stranded tripartite RNA genome, consisting of large (L), medium (M) and small (S) segments, which encode an RNA-dependent RNA polymerase, two envelope glyoproteins ( $\mathrm{Gn}$ and $\mathrm{Gc}$ ) and nucleocapsid $(\mathrm{N})$ protein, respectively. Insects and arthropods serve as vectors of viruses in the Bunyaviridae, except for hantviruses, which instead are harbored by rodents. However, phylogenetically distinct soricomorph-associated hantaviruses have been discovered in widely separated geographical regions spanning four continents. This new finding strongly suggests that evolutionary record of hantaviruses is far more complex and ancient than originally expected. Severe fever with thrombocytopenia syndrome (SFTS) is an emerging infectious disease recently described in northeast and central China. The causative agent of SFTS is phylogenetically classified to genus phlebivirus, but unlike to other member in genus phlebovirus, SFTV transmit by ticks. This review provides a brief overview of hantavirus and hantavirus infection and describes about two newly appeared viruses in the family Bunyaviridae. 